\title{
POTRET KEMISKINAN DALAM KUMPULAN CERITA PENDEK TAWA GADIS PADANG SAMPAH KARYA AHMAD TOHARI
}

\section{(Portrait of Poverty in a Collection of Short Stories the Tawa Gadis Padang Sampah by Ahmad Tohari)}

\author{
Hubbi Saufan Hilmi ${ }^{\mathrm{a}}$ dan Achmad Sultoni ${ }^{\mathrm{b}}$ \\ ${ }^{a}$ Universitas Sebelas Maret Surakarta \\ Jalan Ir. Sutami 36 A, Surakarta, Jawa Tengah \\ Telepon (0271) 646994 \\ ${ }^{b}$ Universitas Muhammadiyah Purwokerto \\ Jalan Raya Dukuh Waluh, Purwokerto, Jawa Tengah \\ Telepon (0281) 636751 \\ Pos-el: hubbyshilmy@gmail.com,achmadsultoni31@yahoo.co.id \\ tanggal naskah masuk 10 Desember 2018 \\ tanggal akhir penyuntingan 16 Juni 2019
}

\begin{abstract}
This study aims to describe the portrait of poverty that exist in a collection of short stories the Tawa Gadis Padang Sampah by Ahmad Tohari. The method of this research is qualitative desktiptif method with the study of the sociology of literature. The source of the data in this study is a collection of short stories the Tawa Gadis Padang Sampah by Ahmad Tohari, book the theory of sociology of literature and related journals. The data in this research in the form of sentences that indicate problems in research. Data collection techniques in the study is the analysis of the techniques document. Data analysis techniques using interactive analysis techniques (interactive model of analysis). The results showed that the portrait of poverty in a collection of short stories the Tawa Gadis Padang Sampah by Ahmad Tohari is shown by the residence or the place of residence, employment or profession of a character who was involved the tevye, consumption or food, until the purchasing power of the character, as well as the role of a character in the short story.
\end{abstract}

Keywords: a collection of short stories the Tawa Gadis Padang Sampah and portraits of poverty

\begin{abstract}
Abstrak
Penelitian ini bertujuan untuk mendeskripsikan potret kemiskinan yang ada dalam kumpulan cerpen Tawa Gadis Padang Sampah karya Ahmad Tohari. Metode penelitian ini ialah metode desktiptif kualitatif dengan kajian sosiologi sastra. Sumber data dalam penelitian ini ialah kumpulan cerpen Tawa Gadis Padang Sampah karya Ahmad Tohari, buku teori sosiologi sastra dan jurnal terkait. Data dalam penelitian ini berupa kalimatkalimat yang menunjukkan masalah dalam penelitian. Teknik pengumpulan data dalam penelitian ini ialah teknik analisis dokumen. Teknik analisis data menggunakan teknik analisis interaktif (interactive model of analysis). Hasil penelitian menunjukkan bahwa potret kemiskinan dalam kumpulan cerpen Tawa Gadis Padang Sampah karya Ahmad Tohari ditunjukkan oleh hunian atau tempat tinggal para tokohnya, pekerjaan atau profesi yang digeluti para tokohnya, konsumsi atau makanan, sampai daya beli para tokohnya, serta peranan tokoh dalam kisahan cerita pendek tersebut.
\end{abstract}

Kata-kata kunci: Kumpulan Cerpen Tawa Gadis Padang Sampah dan Potret Kemiskinan 


\section{PENDAHULUAN}

Karya sastra merupakan hasil imajinasi yang mencerminkan manusia dan kehidupannya serta menggunakan bahasa sebagai media penyampainnya, baik lisan maupun tulis. Terciptanya suatu karya sastra tidak lepas dari hasil pengamatan, pemikiran, refleksi, dan rekaman budaya pengarang terhadap suatu hal yang terjadi terkait kehidupannya, baik yang terjadi dalam dirinya sendiri dan tentu saja yang terjadi di masyarakat sekitarnya.

Karya sastra merupakan struktur dunia rekaan, artinya realitas dalam karya sastra adalah realitas rekaan yang tidak sama dengan realitas dunia nyata. Bahan dari dunia nyata telah diolah sesuai dengan idealisme dan imajinasi pengarang sehingga kebenaran dalam karya sastra itu adalah kebenaran menurut idealnya pengarang (Noor, 2010: 13).

Lebih lanjut Nurgiyantoro (2007: 2) menjelaskan bahwa karya sastra sebagai karya yang imajiner, karya fiksi menawarkan berbagai permasalahan manusia dan kemanusiaan, hidup dan kehidupan. Pengarang menghayati permasalahan tersebut dengan penuh kesungguhan yang kemudian diungkapkannya kembali melalui sarana fiksi sesuai dengan pandangannya. Dengan kepekaannya seorang pengarang secara intens mencermati fenomena yang berkembang dalam masyarakat, merasakan pahit getirnya kehidupan, lalu mengartikulasikan dalam bahasa seni yaitu sastra. Oleh karena itu, selain imajinasi dan pemikiran, suatu karya sastra sangat dipengaruhi oleh latar sosial, budaya, maupun latar pendidikan si pengarang.

Salah satu jenis karya sastra yang banyak digandrungi para pembaca ialah cerpen atau cerita pendek. Stanton (2012: 76) mengungkapkan bahwa cerita pendek haruslah berbentuk padat, di dalamnya pengarang menciptakan karakter-karakter, semesta mereka, dan tindakan-tindakannya sekaligus secara bersamaan.
Pemahaman yang baik terhadap suatu karya sastra dicapai dengan sikap kritis pembacanya (Nurgiyantoro, 2007: 56). Ada beberapa cara untuk memahami suatu karya sastra, dalam hal ini ialah memahami karya sastra berupa cerita pendek, salah satu caranya ialah dengan melakukan penelitian terhadap karya sastra (cerita pendek) tersebut. Noor (2010: 3) mengungkapkan bahwa dalam penelitian sastra sangat membutuhkan bantuan dari ilmu lain yang relevan. Sumbangan ilmu lain tersebut bermanfaat dalam penelitian ragam aspek tertentu dalam suatu karya sastra secara bersama-sama, misalnya untuk meneliti aspek-aspek sosial dalam suatu karya sastra dibutuhkan pengetahuan tetang sosial. Pendekatan dengan sosiologi sastra dapat dimanfaatkan untuk menjelaskan atau mendeskripsikan suatu karya sastra yang kental dengan aspek-aspek sosial di dalamnya.

Penelitian ini menggunakan pendekatan sosiologi sastra, kajian sosiolgi sastra adalah kajian terhadap karya sastra yang dilatarbelakangi oleh fakta bahwa adanya suatu karya sastra tidak dapat terlepas dari realitas sosial yang ada dan terjadi di lingkungan si pengarang atau di lingkungan masyarakat. Endraswara (2008: 79) mengungkapkan bahwa sosiologi sastra adalah penelitian yang terfokus pada masalah manusia, sebab sastra sering mengungkapkan perjuangan umat manusia dalam menentukan masa depannya, berdasarkan imajinasi, perasaan, dan intuisi.

Penelitian ini memilih mengkaji kumpulan cerpen karya Ahmad Tohari, Ahmad Tohari sendiri dikenal dengan karya-karyanya yang konsisten menampilkan nilai-nilai lokalitas dan kehidupan sosial masyarakat, khususnya masyarakat Banyumas. Tidak hanya dalam karyanya, Ahmad Tohari dalam kehidupan sehari-hari juga dikenal dengan sosok yang sangat sederhana.

Kumpulan cerpen karya Ahmad Tohari yang dikaji dengan pendekatan sosiologi sastra dalam penelitian ini ialah 
kumpulan cerpennya yang berjudul Tawa Gadis Padang Sampah yang diterbitkan oleh penerbit Kunca Wacana pada tahun 2017. Kumpulan cerpen Tawa Gadis Padang Sampah terdiri dari beberapa cerpen diantaranya cerpen yang berjudul Anak ini Mau Mengencingi Jakarta? yang pernah dimuat di Kompas edisi Minggu 13 Septemper 2015, cerpen Gulai Kam-bhing dan Ibu Rapilus yang pernah dimuat di Kompas 4 Desember 2016, cerpen Komedi Si Bugil dan Spanduk Lusuh yang pernah dimuat di majalah Horison edisi Juli 2016, cerpen SK Pensiun yang pernah dimuat dalam "Cerita Cinta Indonesia", 40 Tahun Gramedia Pustaka Utama, 2014, cerpen Tawa Gadis Padang Sampah yang juga menjadi judul kumpulan cerpen ini, cerpen Paman Klungsu dan Kuasa Peluitnya yang penah dimuat Kompas edisi Minggu, 5 Februari 2017, dan Cerpen Alkisah Sal Mencari Kang Mad: Hormat Sepanjang Masa buat Biyung Sal.

Kumpulan cerpen dengan judul Tawa Gadis Padang Sampah karya Ahmad Tohari menggambarkan secara detail tentang sosiokultur yang ada di lingkungan si pengarang (Ahmad Tohari). Kumpulan cerita pendek tersebut secara umum menggambarkan kisah-kisah masyarakat kelas bawah yang merdeka dan bahagia dengan segala kekurangan dan keterbatasannya. Kehidupan realitas masyarakat miskin ditampilkan pengarang mulai dari cerpen pembuka sampai cerpen penutup dalam kumpulan cerita pendek tersebut yang memang realitanya terjadi dalam kehidupan sehari-hari.

Ada tiga perspektif dalam mengkaji karya sastra dengan pendekatan sosiologi sastra, seperti yang diungkapkan oleh Laurenson dan Swingewood (dalam Endraswara, 2008: 79), yaitu: (1) penelitian yang memandang karya sastra sebagai dokumen sosial yang di dalamnya merupakan refleksi situasi pada masa sastra itu diciptakan, (2) penelitian yang mengungkapkan sastra sebagai cermin situasi sosial penulisnya, dan (3) penelitian menangkap sastra sebagai manifestasi peristiwa dan keadaan sosial budaya.

Berdasar pada hal tersebut, maka penelitian ini bertujuan untuk mengetahui dan mendeskripsikan potret-potret kemiskinan dalam kumpulan cerpen Tawa Gadis Padang Sampah karya Ahmad Tohari.

\section{LANDASAN TEORI}

Pendekatan sosiologi sastra ialah pendekatan terhadap karya suatu karya sastra yang menitikberatkan atau memperhatikan aspek-aspek sosiokultur terkait sebuah karya sastra itu sendiri. Ratna (2003: 1) mengungkapkan bahwa sosiologi sastra sendiri berasal dari bahasa Yunani, yakni dari kata sosio yang mempunyai arti bersama-sama, bersatu, kawan dan teman, dan kata logi yang mempunyai arti sabda, perkataan, perumpamaan. Selanjutnya kedua kata tersebut mengalami perubahan makna, sosio berarti masyarakat dan $\log i$ berarti ilmu. Jadi, sosiologi berarti ilmu pengetahuan yang mempelajari asal usul, pertumbuhan, suatu yang terjadi dalam lingkungan masyarakat. Kata sastra berasal dari kata Sas (Sansekerta) yang berarti mengarahkan, mengajar, memberi petunjuk, dan intrusksi, sementara akhiran tra berarti alat, saran. Jadi sastra ialah kumpulan alat mengajar, buku petunjuk, atau pengajaran yang baik.

Sosiologi sastra sendiri menurut Jabrohim (2003, 158-159) mengungkapkan bahwa sosiologi sastra adalah pendekatan terhadap karya sastra yang mempertimbangkan segi-segi kemasyarakatan oleh beberapa penulis. Tujuan penelitian ini untuk mendapatkan gambaran yang lengkap, utuh, dan menyeluruh tentang hubungan timbal balik antara sastrawan, karya sastra, dan masyarakat.

Lebih lanjut Damono (2003: 17) menyatakan bahwa pendekatan sosiologi sastra adalah pendekatan telaah sastra berdasarkan sosiologi pengarang yang 
mempermasalahkan status sosial, ideologi sosial, dan lain-lain yang menyangkut pengarang sebagai penghasil sastra.

Wellek dan Warren (1993: 111) membagi sosiologi sastra menjadi tiga bagian, yaitu: (1) sosiologi pengarang, pendekatan ini terutama membicarakan tentang status sosial ideologi sosial pengarang sebagai penghasil karya sastra, (2) sosiologi karya sastra, membicarakan tentang masalah sosial yang terdapat dalam karya sastra, (3) sosiologi sastra yang membicarakan tentang suatu penerimaan masyarakat terhadap karya sastra. Dalam penelitian ini akan dibahas tentang sosiologi karya sastra, yang membicarakan tentang masalah sosial yang terdapat dalam karya sastra.

Cerpen ialah salah satu karya hasil imajinasi yang mencerminkan kehidupan penulis dan masyarakatnya. Poe (dalam Nurgiyantoro, 2007: 10) menyebutkan bahwa cerpen adalah sebuah cerita yang selesai dibaca dalam sekali duduk, kira-kira berkisar setengah sampai dua jam. Pendapat lain menyatakan bahwa cerita pendek adalah penyajian suatu keadaan tersendiri atau suatu kelompok keadaan yang memberikan kesan tunggal pada jiwa pembaca.

Unsur-unsur yang membangun cerita pendek terdiri dari unsur intrinsik dan ekstrinsik. Unsur intrinsik adalah unsur yang membangun karya dari dalam cerpen itu sendiri, dalam cerpen terdapat beberapa unsur instrinsik diantaranya ialah tema, alur/ plot, tokoh dan penokohan, setting/latar dan sebagainya, sementara unsur ekstrinsik adalah unsur yang membangun dan berada di luar karya sastra.

Tema cerita adalah ide atau gagasan dalam sebuah cerita. Stanton dan Kenny (dalam Wahyuningtyas dan Wijaya Heru S., 2011: 2) mengungkapkan bahwa tema adalah makna yang dikandung oleh sebuah cerita. Hutagalung dalam Wiyatmi (2008: 18) mengatakan bahwa tema adalah persoalan yang berhasil menduduki tempat dalam cerita dan bukan pikiran pengarang.
Penelaah atau pembaca bukan memahami pengarangnya, melainkan karya sastranya. Alur (plot) menurut Abrams (dalam Burhan Nurgiyantoro, 2007: 113) ialah struktur peristiwa-peristiwa sebagaimana yang terlihat dalam pengurutan dan penyajian berbagai peristiwa tersebut untuk mencapai efek emosional dan efek artistik tertentu. Dengan demikian, plot merupakan perpaduan unsur-unsur yang membangun cerita sehingga merupakan kerangka utama cerita.

Tokoh dan penokohan, tokoh ialah karakter yang diciptakan pengarang dalam sebuah cerita, sementara itu penokohan ialah cara pengarang menggambarkan arakter yang telah diciptakan tersebut dalam sebuah cerita, entah itu nantinya diperankan untuk menjadi seorang yang antagonis ataupun protagonis. Abrams (dalam Burhan Nurgiyantoro, 2007: 165) mengungkapkan bahwa tokoh cerita adalah orang-orang yang ditampilkan dalam suatu karya naratif yang oleh pembaca ditafsirkan memiliki kualitas moral dan kecenderungan tertentu, seperti yang diekspresikan dalam ucapan dan apa yang dilakukan dalam tindakan.

Latar/ setting adalah penggambaran tempat, waktu dan keadaan sosial yang terjadinya sebuah cerita dalam karya sastra. Abrams (dalam Nurgiyantoro, 2007: 216) mengungkapkan bahwa latar juga dapat diartikan keterangan tempat, hubungan waktu, dan lingkungan sosial tempat terjadinya peristiwa-peristiwa yang diceritakan. Latar memberikan deskripsi latar karya sastra yang dapat dibedakan dalam tiga unsur pokok, yaitu tempat, waktu, dan sosial. Latar tempat adalah penggambaran lokasi terjadinya peristiwa yang diceritakan dalam sebuah karya fiksi. Latar waktu berhubungan dengan masalahmasalah "kapan" terjadinya peristiwa yang diceritakan. Latar lingkungan sosial berhubungan dengan tata cara kehidupan sosial masyarakat mencakup berbagai masalah yang kompleks dalam cerita, misalnya dapat berupa kebiasaan hidup, adat 
istiadat, tradisi keyakinan, pandangan hidup, cara berpikir, dan bersikap

Penelitian yang cukup relevan dalam penelitian ini ialah penelitian yang dilakukan oleh Syahrizal Akbar, Retno Winarni, dan Andayani (2013) dengan judul Kajian Sosiologi Sastra dan Nilai Pendidikan dalam Novel Tuan Guru Karya Salman Faris. Hasil penelitiannya menunjukkan bahwa sebagian besar masyarakat Lombok dalam novel Tuan Guru karya Salman Faris mempunyai anggapan bahwa tuan guru merupakan sosok yang mampu memberikan garansi masuk surga, doa yang dipanjatkan tuan guru lebih cepat diijabah oleh Allah disbanding manusia lainnya dan masyarakat memandang tidak ada cela sedikitpun terhadap sosok tuan guru. Latar belakang sosial budaya masyarakat mencakup adat dan kepercayaan, pekerjaan, pendidikan, agama, tempat tinggal, bahasa, dan suku. Persamaannya dengan penelitian ini ialah sama-sama mengkaji sebuah karya sastra dengan pendekatan sosiologi sastra, sementara perbedaannya dengan penelitian ini ialah objek kajiannya.

\section{METODE PENELITIAN}

Jenis penelitian ini ialah deskriptif kualitatif dan menggunakan metode analisis isi. Kumpulan cerita pendek dengan judul Tawa Gadis Padang Sampah karya Ahmad Tohari menjadi sumber data utama dalam penelitian ini dan sumber data lainnya ialah buku teori dan jurnal-jurnal yang relevan dengan penelitian, sementara itu data dalam penelitian ini yakni kata-kata dan kalimat yang menggambarkan latar belakang sosial budaya dalam cerita pendek Tawa Gadis Padang Sampah karya Ahmad Tohari.

Teknik pengumpulan data dalam penelitian ini ialah analisis dokumen. Triangulasi dalam penelitian ini menggunakan triangulasi teori dalam menganalisis data dengan menggunakan perspektif dari berbagai teori untuk membahas permasalahan yang dikaji. Pendekatan atau kajian yang digunakan dalam penelitian ini aalah kajian sosiologi sastra. Kajian ini digunakan untuk mengetahui latar belakang sosial budaya masyarakat dalam kumpulan cerita pendek Tawa Gadis Padang Sampah karya Ahmad Tohari. Teknik analisis data dalam penelitian ini menggunakan teknik analisis interaktif (interactive model of analysis).

\section{HASIL DAN PEMBAHASAN}

\section{1) Analisis Unsur Instrinsik dalam Kumpulan Cerpen Tawa Gadis Padang Sampah Karya Ahmad Tohari}

Karya sastra dalam hal ini ialah cerita pendek, cerita di dalamnya disusun rapi oleh unsur yang ditampilkan pengarang dalam cerita tersebut. Ialah unsur intrinsik yang secara sengaja ditampilkan oleh pengarang agar cerita di dalam suatu karya sastra berjalan dan sesuai dengan apa yang diimajinasikan dan ingin disampaikan kepada para pembaca. Unsur intrinsik yang membangun sebuah cerita pendek ialah berupa tema, tokoh dan penokohan, latar/ setting, alur/ plot, dan sebagainya. Kumpulan cerita pendek Tawa Gadis Padang Sampah memiliki tema yang hampir serupa antara satu cerpen dengan cerpen lainnya.

Secara garis besar tema yang terdapat dalam kumpulan cerpen Tawa Gadis Padang Sampah karya Ahmad Tohari ini ialah mengangkat cerita tentang kehidupan rakyat miskin.

Cerita pendek Anak ini Mau Mengencingi Jakarta? menjadi pembuka cerita pendek dalam kumpulan cerita pendek Tawa Gadis Padang Sampah, mengisahkan kehidupan orang-orang pinggir rel kereta api yang merdeka dan bahagia walaupun dalam keadaan materi yang serba terbatas diwakilkan penulis oleh kisahan seorang laki-laki, anak kecil, dan seorang perempuan. Ketiga tokoh ini bermalam di semak-semak sepanjang rel kereta api.

Cerpen Gulai Kam-bhing dan Ibu Rapilus mengisahkan tentang dua orang laki-laki yang sedang menikmati hidangan 
gulai di warung tenda pinggir jalan. Kisah dalam cerpen ini mengisahkan betapa pentingnya pengetahuan tentang hayat dan betapa pentingnya menutupi kebenaran demi kebaikan bersama.

Cerpen ketiga yakni SK Pensiun, mengisahkan kisah cinta yang universal dari seorang lelaki yang sudah pension berusia enam puluh tujuh tahun yang menikahi seorang janda penjual rujak berusia empat puluh tahunan, belum genap sebulan menikah lelaki pensiun tersebut meninggal dunia. Cerpen berikutnya, Tawa Gadis Padang Sampah, mengisahkan kegembiraan seorang pemulung yang mendapatkan pasangan dari sepatu yang sebelumnya ditemukan di sebuah tempat tumpukan sampah di pinggiran kota.

\section{Cerpen Paman Klungsu dan}

Peluitnya yang mengisahkan tentang seorang tukang pengatur jalan raya yang memiliki keterbatasan fisik di sekitar jalan simpang tiga dekat pasar. Cerpen yang terkahir ialah Alkisah Sal Mencari Kang Mad: Hormat Sepanjang Masa buat Biyung Sal. Cerpen ini mengisahkan pengorbanan dan perjuagan sebuah keluarga pada masa penjajahan Belanda, lalu setelah kemerdekaan dilupakan begitu saja.

Tokoh dan penokohon dalam kumpulan cerpen Tawa gadis Padang Sampah karya Ahmad Tohari diantaranya ialah tokoh seorang laki-laki penyayang, seorang naka laki-laki berumur lima tahunan, dan seorang perempuan dengan make-up tebal disinyalir sebagai seorang penjaja birahi dalam cerpen Anak ini Mau Mengencingi Jakarta?.

Cerpen Gulai Kam-bhing dan Ibu Rafilus dengan tokohnya ialah tokoh saya yang berbadan kerempeng, digambarkan sebagai seorang yang cerdas, dan tidak gegabah. Tokoh Jubedi yang berbadan gemuk dan berperut buncit, digambarkan sebagai seorang yang tidak peka dan gegabah, serta emosional. Tokoh perempuan pelayan warung yang digambarkan sebagai tokoh yang pembohong.
Tokoh dan penokohan dalam cerita pendek Si Bugil dan Spanduk Lusuh ialah tokoh Sontokliwon yang digambarkan sebagai seorang pemuda kampung yang maniak dangdut dan berperangai tenang dan halus. Tokoh $\mathrm{Si}$ Bugil digamabarkan sebagai sosok perempuan gila yang berjalan tanpa busana. Tokoh Cakil digambarkan sebagai seorang anggota organisasi politik, sombong dan arogan. Perempuan kampun digambarkan sebagai seorang yang baik hati, penyabar dan lembut. Cerpen $S K$ Pensiun mempunyai tokoh dan penokoha, diantaranya ialah tokoh Pak Kirom seorang pensiunan mantra pasar, penyabar dan penyayang. Tokoh Salsi anak tokoh Pak Kirom, digambarkan sebagai seorang anak yang sangat patuh dan sangat menyayangi Pak Kirom. Tokoh yu Jembar, seorang janda miskin penjual rujak dengan empat anak yang dinikahi oleh tokoh Pak Kirom. Tokoh Pak Pahing teman sesama pensiunan tokoh Pak Kirom, tokoh Pak Slamet digambarkan sebagai teman pensiunan tokoh Pak Kirom.

Tokoh dan penokohan cerita pendek Tawa Gadis Padang Sampah ialah tokoh Carmi, gadis kecil periang dan seorang pemulung paling belia. Tokoh Korep digambarkan sebagai anak laki-laki teman baik tokoh Carmi dan pemulung belia, dengan wajah bekas luka di bagian atas matanya. Tokoh Carmin seorang lelaki dewasa pengemudi truk sampah, yang baik hati. Tokoh dan penokohan cerita pendek Paman Klungsu dan Peluitnya diperankan oleh tokoh Paman Klungsu yang digambarkan sebagai seorang lelaki dewasa dengan keterbatasan fisik, berjalan pincang karena kaki kirnay lebih pendek dan kecil daripada kaki kanannya. Tokoh Paman Klungsu sehari-hari bekerja sebagai sukarelawan pengatur lalu lintas jalan raya di simpang tiga dekat pasar dengan rompi lusuh dan peluitnya. Tokoh Yu Binah seorang perempuan pedagang nasi rames yang baik hati. Tokoh Yu Binah menjadi sosok yang sangat dikagumi oleh tokoh Paman Klungsu karena gerak tangan $\mathrm{Yu}$ Binah saat menyiapkan nasi rames dan kebaikan hati Yu Binah kepadanya. 
Tokoh dan penokohan dalam cerpen Alkisah Sal Mencari Kang Mad: Hormat Sepanjang Masa buat Biyung Sal ialah terdiri dari tokoh Sal, seorang ibu berusia 24 tahun dengan tiga orang anak. Layaknya ibu dan istri pada umumnya, tokoh Sal sangat menyayangi anak dan sumainya, yakni tokoh Kang Mad. Tokoh Kang Mad digambarkan sebagai pemimpin para pejuang di desanya untuk melawan Belanda dan menjadi buronan Belanda. Tokoh Nenek Nyami seorang janda renta. Tokoh Santoyib dan tokoh Kantun digambarkan sebagai teman seperjuangan Kang Mad, tokoh Santoyib meninggal tertembak prajurit Belanda dan tokoh Kantun digambarkan sebagai tokoh yang terluka parah karena tembakan prajurit Belanda. Tokoh prajurit Belanda, digambarkan sebagai prajurit yang kejam dan beringas. Tokoh Limun digambarkan sebagai adik dari tokoh Sal yang sangat penurut. Tokoh Juned digambarkan sebagai seorang pejuang kemerdekaan yang membantu tokoh Sal mencari tokoh Kang Mad. Tokoh Mbok Makri digambarkan sebagai perempuan yang baik dan tangguh, ia membantu tokoh Sal untuk menyeberangi sungai. Tokoh Mbok Makri juga digambarkan sebagai tokoh yang berprofesi sebagai pedagang hasil hutan.

Latar/ setting dalam kumpulan cerita pendek Tawa Gadis Padang Sampah karya Ahmad Tohari ini diantaranya ialah cerita pendek Anak ini Mau Mengencingi Jakarta? berlatar tempak di sepanjang rel kereta api sebelum masuk stasiun Pasar Senin, dan berlatar waktu pada malam hari. Cerita pendek Gulai Kam-bhing dan Ibu Rapilus berlatar tempat di sebuah tempat makan di pinggir jalan dan berlatar waktu pada pagi sampai siang hari. Cerita pendek Komedi Si Bugil dan Spanduk Lusuh berlatar tempat di sebuah perkampungan dan berlatar waktu pada pagi hari. Cerita pendek SK Pensiun berlatar tempat di rumah Pak Kirom, rumah Salsi, dan di kantor urusan agama, sementara latar waktunya terjadi pada pagi dan malam hari. Cerita pendek Tawa Gadis Padang Sampah berlatar tempat di sebuah tempat pembuangan sampah di pinggir kota dan latar waktunya terjadi dari pagi sampai siang hari. Cerita pendek Paman Klungsu dan Kuasa Pluitnya berlatar tempat di simpang tiga jalan dekat dengan pasar dan di warung $\mathrm{Yu}$ Binah, latar waktnya sendiri terjadi pada pagi sampai siang hari. Cerita pendek Alkisah Sal Mencari Kang Mad: Hormat Sepanjang Masa buat Biyung Sal berlatar tempat di sebuah kampung, di sungai, dan di rumah Mbok Makri. Latar/ setting waktu dalam cerita pendek Alkisah Sal Mencari Kang Mad: Hormat Sepanjang Masa buat Biyung Sal terjadi pada Juli 1945, pada malam, pagi, dan siang hari.

Alur/ plot yang digunakan Ahmad Tohari dalam kumpulan cerita pendek Tawa Gadis Padang Sampah diantaranya ialah alur maju yang digunakan Ahmad Tohari dalam cerpen Anak ini Mau Mengencingi Jakarta?. Hal tersebut terlihat dari awal cerita yang menampilkan adegan ketika sebuah kereta tiba-tiba terhenti menjelang stasiun Pasar Senen dan adegan selanjutnya dilanjutkan dengan cerita kehidupan masyarakat rel yang oleh penulis diwakilkan dengan tokoh-tokoh yang dihadirkan. Alur maju juga dipakai dalam cerita pendek selanjutnya, yakni Gulai Kam-bhing dan Ibu Rapilus yang oleh penulis mengawali ceritanya dengan pertemuan dua kawan lama di sebuah tempat makan pinggir jalan dan cerita diakhiri dengan perpisahan keduanya. Begitu juga dengan cerita pendek dengan judul Komedi Si Bugil dan Spanduk Lusuh yang penulisnya mulai dengan terlenih dahulu memperkenalkan nama, karakter, dan ciri-ciri tokoh yang ada dalam ceritanya, kemudian dilanjutkan dengan konflik dan diakhiri dengan penyelesaian konflik yang terjadi sebelumnya dalam cerita.

Berbeda dengan alur dalam cerita pendek karya Ahmad Tohari sebelumnya, cerita pendek SK Pensiun menggunakan alur mundur, hal ini dibuktikan ketika cerita yang diawali dengan kematian tokoh Pak Kirom, kemudian dilanjutkan dengan ingatan-ingatan tokoh Salsi tentang pernikahan mendiang ayahnya tersebut 
dengan yu Jembar, dan cerita diakhiri ketika salah satu teman sesama pensiunan meminta tokoh Salsi mencari SK pensiunan bapaknya ketika upacara pemakaman berakhir, dan setelah mendapatkan penjelasan dari teman pensiunan bapaknya tersebut, tokoh Salsi mengerti maksud bapaknya menikahi yu Jembar.

Alur/ plot cerita dalam cerita pendek Tawa Gadis Padang Sampah menggunakan alur maju, hal tersebut terlihat dari jalannya cerita yang pada awal cerita mendeskripsikan dan memperkenalkan para tokohnya. Alur/ plot cerita pendek Paman Klungsu dan Kuasa Peluitnya juga menggunakan alur maju, hal tersebut terlihat dari dimulainya cerita dengan penggambaran situasi jalan simpang tiga dekat pasar yang sibuk dan diurusi oleh seorang pria bernaman Klungsu, kemudian dilanjutkan dengan memperkenalkan sosok Paman Klungsu dan cerita diakhiri dengan berlalunya Paman Klungsu dari warung Yu Binah setelah sebelumnya mendapat protes dan sadar pluitnya sangat bau. Kemudian cerita pendek yang terakhir yakni Alkisah Sal Mencari Kang Mad: Hormat Sepanjang Masa buat Biyung Sal menggunakan alur maju, hal tersebut terihat juga ketika penulis mendeskripsikan para tokohnya dan memperkenalkan setiap tokoh yang hadir dalam cerita, cerita dimulai dengan sebuah diskusi para pejuang pada suatu malam, kemudian dilanjutkan dengan penggerebekan oleh tentara Belanda, sampai pada akhir cerita mengisahkan tentang kemerdekaan Indonesia dan akhir hidup para pejuang dan keluarga para pejuang yang tidak pernah diingat jasa-jasanya.

\section{2) Potret Kemiskinan dalam Kumpulan Cerpen Tawa Gadis Padang Sampah Karya Ahmad Tohari}

Karya sastra ialah cerminan kehidupan suatu masyarakat. Karya sastra melalui imajinasi pengarangnya menampilkan cerita rekaan yang menampilkan aspek sosial budaya di suatu lingkungan masyarakat. Latar sebuah cerita yang mencerminkan aspek sosial budaya dapat berupa pendidikan, bahasa, agama, tempat tinggal, adat istiadat (kebiasaan), suku, dan pekerjaan. Latar belakang sosial budaya yang ditampilkan pengarang inilah yang menjadi ciri khas pada karya-karya pengarang.

Latar belakang sosial yang menjadi fokus dalam penelitian ini ialah tentang cerminan kemiskinan dalam kumpulan cerita pendek Tawa Gadis Padang Sampah karya Ahmad Tohari. Potret-potret kemiskinan dalam kumpulan cerita pendek tersebut tampak dalam keseluruhan cerita pendek yang ada dalam kumpulan cerpen tersebut.

Adapun potret kemiskinan dalam kumpulan cerita pendek Tawa Gadis Padang Sampah karya Ahmad Tohari tampak pada kutipan berikut.

...., sebagian besar mereka masih terbaring dalam gubuk-gubuk kardus yang menyandar ke tembok pembatas jalur-jalur rel. Ada yang hanya tampak kaki, dan tubuh mereka terlindung di bawah atap sangat rendah lembaran rongsok" (Tohari, 2017: 2).

Kutipan tersebut dikutip dari cerpen yang berjudul Anak ini Mau Mengencingi Jakarta?. tampak pada kutipan tersebut, potret kemiskinan dalam cerpen Berjudul Anak ini Mau Mengencingi Jakarta? terlihat jelas dari tempat tinggal para tokohnya, yakni di rel kereta api dengan beberapa kardus sebagai tempat berteduh mereka.Tempat tinggal menjadi sebuah indikator tingkat perekonomian seseorang di Indonesia.

Potret kemiskinan berdasar tempat tinggal juga tampak dalam cerpen berjudul SK Pensiun. Perihal yang menyatakan demikian terlihat pada kutipan berikut.

"Ya nama dia memang Jembar, namun rumahnya sempit sekali. Kamu tahu, kan? Hanya ada satu balai-balai, itu untuk Jembar dan dua anaknya yang masih kecil. Anak yang lain tidur di bangku panjang atau di surau" (Tohari, 2017: 42). 
Cuplikan percakapan tersebut diutaraka oleh salah seorang tokoh dalam cerpen SK Pensiun, yakni Pak Kirom. Pak Kirom menikahi seorang janda penjual rujak bernama Yu Jembar yang memiliki empat orang anak. Berdasar pada kutipan tersebut, terlihat bahwa $\mathrm{Yu}$ Jembar seorang janda yang kurang mampu dan memiliki tempat tinggal yang sangat sempit. Hal tersebut merupakan sebuah potret kemiskinan yang tercipta dalam cerpen berjudul SK Pensiun.

Potret kemiskinan lainnya juga terlihat pada cerpen Tawa Gadis Padang Sampah yang tergabung dalam kumpulan cerpen Tawa Gadis Padang Sampah karya Ahmad Tohari dan dijadikan sebagai judul utama kumpulan cerpen tersebut. Potret kemiskinan yang ditandai oleh tempat tinggal dalam cerpen berjudul Tawa Gadis Padang Sampah ini terlihat pada kutipan berikut.

"Carmi tertawa-tawa, tentu karena ada sepasang sepatu di kakinya. Tetapi kedua bocah pemulung itu mau ke mana kiranya? Semua warga padang sampah tahu Carmi dan Korep tak punya rumah untuk pulang" (Tohari, 2017: 53).

Tampak jelas dalam kutipan tersebut bahwa dua tokoh utama dalam cerpen Tawa Gadis Padang Sampah tidak mempunyai hunian tetap untuk tinggal. Cerita dalam cerpen Tawa Gadis Padang Sampah menceritakan bahwa kedua tokoh tersebut dalam kesehariannya mengais rejeki sering beristirahat di bawah pohon ketapang. Hal itu terlihat pada kutipan berikut.

"Maka Korep dan Carmi bergerak ke sisi timur. Di sana ada pohon ketapang yang rindang" (Tohari, 2017: 49).

Cerpen berikutnya yang mencerminkan kemiskinan dalam kumpulan cerpen Tawa Gadis Padang Sampah karya Ahmad Tohari jika dilihat dari segi tempat tinggalnya ialah cerpen yang berjudul $A l$ Kisah Sal Mencari Kang Mad: Hormat Sepanjang Masa buat Biyung Sal. Cerpen ini berbeda dengan cerpen-cerpen sebelumnya yang sangat mungkin bisa kita temui sehari-hari di lingkungan kita. Cerpen terakhir dalam kumpulan cerpen Tawa Gadis Padang Sampah ini berlatar cerita perjuangan kemerdekaan. Tokoh-tokoh dalam cerpen tersebut bertempat tinggal di gubuk-gubuk sebagaimana halnya yang ada dalam sejarah Indonesia. Hal tersebut tampak dalam kutipan berikut.

Tidak sampai dua hari bilik sederhana itupun siap, serba bambu kecuali atapnya yang terbuat dari lapisan daun ilalang. Alas tidurnya menggunakan pelupuh bambu yang langsung digelar di lantai tanah. Dinding sebelah timur menjadi batas bilik itu dengan kandang kambing keluarga makri” (Tohari, 2017: 77).

Tampak jelas dalam kutipan tersebut bahwa Kang Mad yang pada saaat itu diburu oleh Belanda melarikan diri ke hutan dan mendapatkan pertolongan keluarga Makri. Keluarga Makri menyambut dengan tangan terbuka dan memberikan sebidang tanah dekat dengan kandang kambing sebagai tempat Kang Mad membuat hunian bersama istrinya Sal dan anak-anaknya.

Indikator lain yang mencerminkan kemiskinan ialah pekerjaan, dalam kumpulan cerpen Tawa Gadis Padang Sampah karya Ahmad Tohari ditampilkan profesi-profesi yang kurang menguntungkan bahkan tidak jelas yang digeluti oleh para tokohnya, salah satunya ialah pekerja seks. Hal tersebut terlihat dalam kutipan cerpen berjudul Anak ini Mau Mengencingi Jakarta?

"Wajah perempuan yang lelap itu tampak lelah. Tetapi gincu bibir dan bedak pipinya tebal. Entahlah, mungkin perempuan itu tadi malam berjualan birahi sampai pagi”" (Tohari, 2017: 2).

Pagi sudah terang. Sosok perempuan itu menjadi lebih jelas. 
Usianya mungkin empat puluhan. Gincu dan bedak pipinya memang tebal. Atau lebih tebal di awal malam ketika ia mulai berjualan" (Tohari, 2017: 8).

Kedua kutipan tersebut menggambarkan makna tersirat bahwa profesi/ pekerjaan yang digeluti oleh salah satu tokoh dalam cerpen ialah seorang pekerja seks. Pensiunan mantri pasar dan penjual rujak menjadi profesi berikutnya dalam kumpulan cerpen Tawa Gadis Padang Sampah. Kedua profesi itu menjadi satu dalam cerpen berjudul SK Pensiun. Hal tersebut terlihat pada kutipan berikut.

"Pak Kirom, pensiunan mantra pasar, meninggal waktu subuh tadi, kata orang karena serangan jantung" (Tohari, 2017: 35).

"Sebulan yang lalu Pak Kirom memang menikahi yu Jembar, janda beranak empat yang berjualan rujak di sudut perempatan kampung" (Tohari, 2017: 35-36).

Profesi/ pekerjaan lainnya yang mecerminkan kemiskinan dalam kumpulan cerpen Tawa Gadis Padang Sampah ialah pada cerpen yang berjudul Tawa Gadis Padang Sampah sendiri. Profesi/ pekerjaan dalam Cerpen dengan judul Tawa Gadis Padang Sampah ialah supir truk dan pemulung. Hal tersebut terlihat dalam kutipan berikut.

"Dalim tentu manusia dewasa, sopir truk sampah berwarna kuning dengan dua awak. Dia pegawai negeri, suka lepas pakai kacamatanya yang berbingkai tebal. Carmi sebenarnya masih terlalu muda untuk disebut gadis. Korep anak laki-laki yang punya noda bekas luka di atas matanya. Keduanya pemulung paling belia di antara warga padang sampah" (Tohari, 2017: 45).
Potret kemiskinan atas dasar profesi atau pekerjaan dalam kumpulan cerpen Tawa Gadis Padang Sampah karya Ahmad Tohari juga tampak dalam cerpen berjudul Paman Klungsu dan Kuasa Peluitnya. Hal tersebut terlihat pada kutipan berikut.

"Apalagi Paman Klungsu juga serng mendapat uang receh. Itu pemberian sopir-sopir yang merasa bersimpati. Mereka menghargai jasa Paman Klungsu yang punya prakarsa mengatur lalu lintas di simpang tiga" (Tohari, 2017: 56-57).

Kutipan tersebut menunjukkan bahwa tokoh Paman Klungsu berprofesi sebagai seorang sukarelawan pengatur lalu lintas. Pendapatan yang diperoleh tokoh Paman Klungsu sebagai sukarelawan tersebut setiap harinya tidak menentu.

Cerpen Al kisah Sal Mencari Kang Mad: Hormat Sepanjang Masa buat Biyung Sal yang bertemakan perjuangan seorang istri pejuang kemerdekaan mencari suaminya yang tertembak dan menjadi buronan Belanda, profesi dalam cerpen ini pun sangat berbeda yakni sebagai para pejuang. Setelah kemerdekaan, Tokoh Kang Mad diangkat sebagai pamong desa urusan keamanan, sementara istrinya tokoh Sal bekerja sebagai petani dan pedagang nasi rames. Hal tersebut tampak pada kutipan berikut.

"Perang pun usai. Kang Mad membawa Sal dan keempat anaknya keluar dari rumah keluarga Makri, lalu turun gunung kembali ke Dukuh Kidul. Dibangunnya rumah kecil dari kayu dan bamboo di atas puingpuing rumah lama yang sudah menjadi abu. Sal kembali bertani dan berjualan nasi rames di pasar. Kang Mad diangakat menjadi pamong desa urusan keamanan" (Tohari, 2017: 78).

Potret kemiskinan setelah kemerdekaan lainnya dalam cerpen tersebut juga terlihat pada kutipan berikut. 
Tetapi hari ini dua cucu Santoyib sedang antre di balai desa. Mereka akan menebus sepuluh kilo beras miskin yang bermutu rendah. Beras itu dijual negara, beruntung dengan harga subsidi (Tohari, 2017: 79).

Kutipan tersebut menunjukkan bahwa kemiskinan yang diharapkan membaik pasca penjajahan Belanda ternyata masih tetap dialami oleh cucu para tokoh pejuang dalam cerpen tersebut. Tokoh Santoyib ialah tokoh yang diceritakan sebagai teman seperjuangan tokoh Kang Mad. Ia gugur ditembak penjajah Belanda.

Hunian dan pekerjaan ialah salah dua indikator yang muncul sebagai potret kemiskinan dalam kumpulan cerpen Tawa Gadis Padang Sampah karya Ahmad Tohari, indikator lainnya ialah konsumsi atau makanan yang dimakan oleh para tokoh dalam kumpulan cerpen tersebut. Sebungkus mi instan yang dimakan oleh tiga tokoh dalam cerpen berjudul Anak ini Mau Mengencingi Jakarta? merupakan indikator ketidakmampuan para tokoh untuk mendapatkan makanan yang lebih baik atau lebih banyak. Hal tersebut terlihat dalam kutipan berikut.

Di tangan kanan laki-laki itu ada sebungkus mi instan. Di warung kopi seberang jalan, sudut bungkus mi disobek dengan hatihati sekedar untuk membuat lubang. Saset-saset bumbunya dikeluarkan" (Tohari, 2017: 2).

"Tapi aku ingin kuahnya juga Pa". "Kuahnya masih terlalu panas. Lagi pula kamu jangan serakah. Kuah mi selalu buat emak. Dia suka sekali" (Tohari, 2017: 7).

Kemiskinan dari faktor konsumsi tokoh dalam kumpulan cerpen Tawa Gadis Padang Sampah karya Ahmad Tohari juga tampak pada cerpen induknya, yakni cerpen Tawa Gadis Padang Sampah. Hal tersebut terlihat dalam kutipan berikut.
"Korep mengeluarkan pisau kecil pemberian sopir Dalim. Satu mangga ada di tangan kiri. Dengan sekali gerak tersayatlah mangga itu tepat pada batas yang busuk. Carmi menatap permukaan sayatan yang berwarna segar. Liur carmi terbit, tetapi kemudian bergidik karena ada dua belatung muncul di permukaan sayatan" (Tohari, 2017: 49).

Kutipan tersebut menunjukkan bahwa makanan yang dimakan tokoh Korep dan tokoh Carmi ketika beristirahat setelah memulung ialah sebuah mangga busuk. Hal tersebut menunjukkan bahwa kedua tokoh dalam cerpen tawa gadis padang sampah tersebut tidak mempunyai daya untuk mendapatkan makanan, bahkan tidak mempunyai daya untuk membeli sebuah mangga yang masih segar. Hal tersebut juga dipengaruhi oleh faktor perekonomian mereka.

Potret kemiskinan lainnya dalam kumpulan cerpen Tawa Gadis Padang Sampah karya Ahmad Tohari ialah hadirnya tokoh orang gila dalam cerpen Komedi Si Bugil dan Spanduk Lusuh. Hal tersebut terlihat dalam kutipan berikut.

Pagi itu ada perempuan terlantar lewat. Dia muda dan hampir bugil. Tetapi wajahnya tanpa citra jiwa. Tatapan matanya kosong. Semua pejalan kaki yang berpapasan dengan dia menunduk atau membuang muka (Tohari, 2017: 26).

Kutipan tersebut menunjukkan bahwa kondisi salah satu tokoh dalam cerpen berjudul komedi si bugil dan spanduk lusuh sangatlah memperihantinkan, tanpa busana yang layak sehingga semua orang memalingkan wajah dan menundukkan kepalanya ketiak berpapapsan dengan tokoh si bugil. Pemberian peran sebagai orang gila ke tokoh dalam cerpen tersebut merupakan salah satu potret kemiskinan yang tampak dalam cerpen tersebut. 
PENUTUP

\section{Simpulan}

Kisahan dalam kumpulan cerpen Tawa Gadis Padang Sampah karya Ahmad Tohari menampilkan kisahan-kisahan yang banyak kita temui dalam kehidupan seharihari. Potret kemiskinan tersebut tampak dalam beberapa judul cerpen dalam kumpulan cerpen Tawa Gadis Padang Sampah, diantaranya ialah cerpen Anak ini Mau Mengencingi Jakarta? cerpen Komedi Si Bugil dan Spanduk Lusuh, cerpen SK Pensiun, cerpen Tawa Gadis Padang Sampah, cerpen Paman Klungsu dan Kuasa Peluitnya, dan cerpen Al Kisah Sal Mencari Kang Mad: Hormat Sepanjang Masa buat Biyung Sal.

Potret kemiskinan dalam beberpa cerpen tersebut ditandai dengan tempat tinggal atau hunian para tokohnya, pekerjaan para tokohnya, konsumsi atau makanan hingga daya beli makanan para tokohnya, serta peran tokoh yang diberikan pengarang dalam cerpen.

\section{DAFTAR PUSTAKA}

Akbar, S., Retno. W. \& Andayani. (2013). "Kajian Sosiologi Sastra dan Nilai Pendidikan dalam Novel Tuan Guru karya Salman Faris". Jurnal Pendidikan Bahasa dan Sastra. Vol. 1, No. 1.
Damono, D. S. (2003). Sosiologi Sastra: Sebuah Pengantar Ringkas. Jakarta: Gramedia.

Endraswara, S. (2008). Metodologi Penelitian Sastra. Yogyakarta: Pustaka Widyatama.

Jabrohim. (2003). Metodologi Penelitian Sastra. Jakarta: Hanindita Graha Widya.

Noor. R. (2010). Pengantar Pengkajian Sastra. Semarang: Fasindo.

Nurgiyantoro, B. (2007). Teori Pengkajian Fiksi. Yogyakarta: Gajah Mada University Press.

Ratna, N. K. (2003). Paradigma Sastra Sosiologi Sastra. Yogyakarta: Pustaka Pelajar.

Stanton. R. (2012). Teori Fiksi. Yogyakarta: Pustaka Pelajar.

Tohari, A. (2017). Tawa Gadis Padang Sampah. Yogyakarta: Kunca Wacana.

Wahyuningtyas, S. \& Wijaya H. S. (2011). Sastra: Teori dan Implementasinya. Surakarta: Yuma Pustaka.

Wellek, R. \& Austin, W. (1993). Teori Kesusastraan (Terjemahan). Jakarta: Gramedia Pustaka Utama.

Wiyatmi. (2008). Pengantar Kajian Sastra. Yogyakarta: Penerbit Pustaka. 
